\title{
Hubungan Penerimaan Diri dengan Kebersyukuran Siswa MA Bilingual Boarding School
}

\section{(The Relationship Self-Acceptance With Gratitude On Student Of Bilingual Boarding School)}

\author{
Machrozah Eka W' Jainuddin $^{1}$ \\ Fakultas Psikologi dan Kesehatan, Universitas Islam Negeri Ampel Surabaya \\ ekaa.psill@gmail.com
}

\begin{abstract}
Abstrak
Penelitian ini bertujuan untuk mengetahui hubungan penerimaan diri (self- acceptance) dengan kebersyukuran (gratitude) siswa. Sampel penelitian ini adalah siswa yang tinggal di asrama MA Bilingual yang berjumlah 96 siswa. Penelitian ini merupakan penelitian korelasional dengan menggunakan teknik pengumpulan data berupa skala likert yaitu skala penerimaan diri dan skala kebersyukuran yang sudah melalui uji coba. Teknik analisis data yang digunakan adalah analisis korelasi product moment dari Pearson. Hasil penelitian menunjukkan bahwa nilai signifikansi $0.082<$ 0.05 pada tabel correlation, sehingga hipotesis ditolak, yang artinya tidak terdapat hubungan penerimaan diri dengan kebersyukuran siswa.
\end{abstract}

Kata Kunci : Kebersyukuran, Penerimaan Diri

\begin{abstract}
The research aim is to know about relation between self-acceptance with gratitude at adolescent. Sample of this research are 96 students who life at boarding house at Bilingual High School. Research method is used quantitative method research. This research is correlational research used likert scale as a scale to collect data, there are self-acceptance scale and gratitude scale that have been through the tryout. Data analysis technique applies a product moment technique from Pearson. The result showed that significance value $0.082<0.05$ in the correlation table, so that hypothesis that asked are not accepted, it's mean there nosignificant correlation between self-acceptance with gratitude
\end{abstract}

Keyword : Gratitude, Self-Acceptance

\section{Pendahuluan}

Pada dasarnya kondisi ketidakpuasan dirasakan karena kurangnya penerimaan dan minimnya toleransi terhadap masalah hidup yang dihadapi, serta kurangnya sikap syukur kepada Allah yang telah memberikan apa yang sudah dicapai dan dimiliki oleh seseorang. Kebersyukuran adalah rasa berterimakasih dan bahagia sebagai respon penerimaan karunia, baik karunia tersebut dirasakan oleh orang lain atau keadaan nyaman,aman, dan terjadi secara alamiah (Peterson dan Seligman, 2004).

Terdapat banyak faktor yang mempengaruhi kebersyukuran siswa, diantaranya yaitu positive affect yang dimiliki oleh siswa, religiusitas, well-being, dan penerimaan diri. Menurut Tellegen (Diponegoro, 2010) ditandai dengan energy yang tinggi, rasa kenyamanan dan penuh konsentrasi.Sedangkan seseorang dengan afek positif yang rendah ditandai dengan kesedihan, tidak bersemangat. Menurut Rahmat (Puspitasari, dkk, 2005) sebagian remaja memperoleh ketenangan dalam menjalani agamanya.Selain itu, agama memberikan kerangka moral sehingga remaja dapat 
membendingkan tingkah lakunya. Dalam penelitian ini peneliti berfokus pada faktor penerimaan diri kaitannya dengan kebersyukuran pada siswa.

Ryff (1996) mendefinisikan penerimaan diri sebagai suatu keadaan dimana seorang individu memiliki penilaian positif terhadap dirinya, menerima serta mengakui segala kelebihan maupun segala keterbatasan yang ada dalam dirinya tanpa merasa malu atau merasa bersalah terhadap kodrat dirinya. Penerimaan diri adalah salah satu aspek yang penting pada seseorang. Dengan adanya penerimaan diri seseorang akan mampu mengaktualisasikan segala potensi yang dimilikinya. Adanya penerimaan diri akan membantu individu untuk dapat berfungsi secara ideal sehingga individu dapat mengembangkan segala kemampuan dan potensi yang dimiliki dengan optimal.

Kebersyukuran dan penerimaan diri menjadi fenomena yang penting terutama bagi seorang siswa. Dilansir dari artikel Jeffery Froh (2012), bahwa sejak tahun 2006 di United States telah menerapkan program pembelajaran bersyukur kepada siswa siswi yang telah memasuki sekolah menengah atas. Program tersebut mengandung aspek-aspek yang memunculkan perilaku untuk bersyukur, salah satunya yaitu self-improvement, perilaku menolong terhadap sesama, dan adanya rasa percaya bahwa ada keuntungan yang mereka dapatkan dengan bersyukur.Tujuan dibentukknya program pembelajaran mengenai kebersyukuran ini bukan hanya semata untuk membuat siswa mempunyai perilaku yang baik, namun untuk meningkatkan mood, kesehatan mental, dan kepuasan hidup. Selain itu untuk remaja seusia mereka penting untuk memahami kebermaknaan hidup. Bahkan saat ini banyak Negara yang telah menerapkan program pembelajaran tersebut, diantaranya yaitu Australia, Britania Raya, Jepang, dan Singapura.

Dilansir dari artikel Emily Compbell (2013), bahwasanya Mindy Ma dengan rekan kerjanya melihat kebersyukuran yang berbeda. Mereka melakukan sebuah pembentukan karakter bersyukur pada remaja Afrika- Amerika, hal demikian dilakukan agar siswa mampu merespon dengan emosi yang lebih positif akan lingkungan tempat tinggal sekolah mereka yang sangat beresiko dikarenakan perbedaan budaya.

Sebuah penelitian yang telah dilakukan oleh Sagita (2015) mengenai kebersyukuran terhadap santri di pondok pesantren Assalaam menunjukkan bahwa 90\% santri di Assalaam tidak melakukan pelanggaran dan seluruh santri dinyatakan lulus $100 \%$ pada tahun 2013 lalu dengan menghafal alqur'an serta menulis karya tulis dengan bahasa arab atau inggris. Hal ini membuktikan bahwa kebersyukuran yang tinggi telah dimiliki oleh santri Assalaam. Dengan bersyukur dan memiliki rasa optimisme yang tinggi akan membantu santri mencapai kesejahteraan subjektif.

Dalam penelitian ini, lebih dari $80 \%$ siswa Bilingual yang tinggal di asrama melakukan aktivitas sesuai dengan peraturan yang ada baik di sekolah maupun di asrama, yaitu dengan adanya absen sholat wajib maupun sunnah yang harus mereka isi setiap waktu, selain itu siswa siswi menunjukkan prestasi yang baik di sekolah dengan nilai mata pelajaran minimal 6.5, siswa siswi juga menghafal al-qur'an 3 juz dengan tepat waktu, serta tidak melakukan pelanggaran di sekolah maupun asrama. Hal demikian dilakukan untuk mencapai visi dan misi sekolah dalam membentuk siswa yang berprestasi bukan dalam hal akademik, namun juga pada pemebentukan karakter yang positif.

Siswa yang bersekolah dengan berasrama membutuhkan waktu yang lebih banyak untuk mengatur dirinya sendiri. Ia akan dituntut untuk lebih mandiri dan bertanggung jawab atas kehidupannya, bukan hanya pada pencapaian akademik di sekolah namun juga pada kegiatannya diluar sekolah yang mengacu pada peraturan-peraturan di asrama. Dengan hidup berasrama, siswa akan dihadapkan pada permasalahan-permasalahan sesuai dengan tahap perkembangan siswa khususnya remaja. Oleh karenanya dengan kondisi seperti ini, penting bagi siswa untuk memeiliki kebersyukuran terhadap hidupnya.

Dengan sikap syukur, siswa akan terbebas dari hasrat akan terobsesi dari hal-hal yang berada di luar dirinya. Seseorang yang bersyukur akan selalu berterimakasih kepada Allah atas segala yang ia miliki baik maupun buruk. Dikarenakan sadar sepenuhnya atas hakikat dan makna hidup, orang yang bersyukur akan selalu dapat merasakan kebahagiaan dalam segala hal, tak terkecuali disaat mereka ditimpa bencana atau musibah. Orang yang bersyukur menyikapi hal ini dengan tetap berterimakasih kepada Allah atas segala yang telah ia miliki dan tidak mudah kecewa karena yakin bahwa segala yang diberikan Allah saat ini merupakan ketetapan yang terbaik baginya.

Siswa yang berhasil memenuhi kebutuhan dan tugas perkembangannya membuat dirinya memperoleh kepuasan hidup dan juga kebahagiaan yang diyakini dapat membentuk kesejahteraan dalam dirinya. Hal-hal positif seperti kebahagiaan dan kepuasan juga turut berpengaruh dalam 
pembentukan kondisi psikologis yang positif (positive psychological functioning) yang membawa kepada terbentuknya kesejahteraan psikologis (psychological well-being) dalam diri seseorang (Ryff \& Keyes, 1995).Salah satu keutamaan (virtues) yang dimiliki individu untuk bisa memandang hidup secara lebih positif adalah melalui bersyukur.

Beberapa penelitian mengenai kebersyukran yang diteliti dalam lingkup pendidikan, diantaranya yaitu penelitian yang dilakukan oleh Aricioglu (2016) menunjukkan hasil bahwa kebersyukuran mampu meningkatkan kepuasan dan kesejahteraan mahasiswa Turki. penelitian lainnya dilakukan oleh Bilal, Kusuma, Noviani, dan Aprizal (2017) yang menunjukkan bahwa kebersyukuran mampu mempengaruhi afeksi dan kesejahteraan. Dan penelitian yang dilakukan oleh Muniarsih (2013) yang menunjukkan bahwa kebersyukuran memberikan pengaruh yang cukup besar terhadap penerimaan diri yang merupakan salah satu aspek dari well being.

Penelitian dengan hasil yang sama dilakukan oleh Putri (2012) yang melibatkan 340 mahasiswa sebagai subjek penelitinnya. Dalam penelitiannya mendapatkan bahwa kebersyukuran memiliki pengaruh yang besar terhadap penerimaan diri, yang mana penerimaan diri merupakan salah satu aspek dari psychological well-being.

Dengan bersyukur seseorang akan menerima apa yang ada dalam dirinya. Setiap orang memiliki keterbatasan ataupun kekurangan dalam hidup, namun dengan cara menerima keadaan diri apa adanya, dengan rasa terima kasih, pemikiran yang positif, menerima atau mendapatkan sesuatu yang mana pada akhirnya dapat memberikan suatu kebahagiaan, perasaan nyaman dapat meningkatkan rasa syukur. Hal ini sesuai dengan firman Allah SWT dalam surat Luqman ayat 22:

"Dan barang siapa yang menyerahkan dirinya kepada Allah, sedang dia orang yang berbuat kebaikan, maka sesuangguhnya ia telah berpegang kepada buhul tali yang kokoh.Dan hanya kepada Allah-lah kesudahan segala urusan."

Berdasarkan ayat di atas, dapat dikatakan bahwa orang yang bersyukur menerima dan memahami bahwa segala sesuatu yang terjadi pada dirinya adalah kehendak Allah SWT sebagai wujud penerimaan diri dan kelapangan dada.Kebersyukuran lebih kuat terhubung pada emosi positif daripada emosi negatif dan menunjukkan hubungan positif dengan penerimaan diri. Hal demikian didukung penelitian yang dilakukan oleh McCollough, Tsang, \& Emmons (2004), seseorang yang bersyukur memiliki kontrol yang lebih tinggi terhadap lingkungannya, perkembangan personal, dan juga penerimaan diri.

Hal ini didukung oleh Wood, Joseph, dan Maltby (2009) bahwa penerimaan diri mampu memprediksi adanya rasa syukur, dimana penerimaan diri merupakan salah satu aspek dalam mencapai kepuasan hidup. Salah satu teori psikologi dari Carl Rogers (dalam Alwisol, 2009) menyatakan bahwa, ketika individu mempu menginternalisasikan penerimaan diri yang positif maka individu tersebut mendapat kepuasan atas dirinya sendiri. Dengan adanya penerimaan dalam diri akan memunculkan emosi positif, mood positif dan juga kognisi yang positif yang mengarahkan individu untuk bersyukur.

Teori tersebut didukung oleh pernyataan Hurlock (2009) yang mengatakan bahwa individu yang menyukai dirinya maka ia akan mampu menerima dirinya dan ia akan semakin diterima oleh orang lain, dengan kata lain individu dengan penerimaan diri yang baik akan mampu mengarakan ke emosi yang positif salah satunya yaitu dengan mengucap syukur.

Kebersyukuran dan penerimaan diri merupakan satu hal yang berkaitan. Seseorang yang memiliki penerimaan diri yang baik, maka ia mampu melihat diri sendiri dari sisi positif, menerima serta mengakui segala kelebihan maupun segala keterbatasan yang ada dalam dirinya, sehingga akan membuat seseorang akan bersyukur dengan apa yang ia miliki sekarang dan mengarahkan ke emosi yang positif. Selain itu, dengan adanya kebersyukuran dan penerimaan diri akan menyebabkan remaja memberikan evaluasi yang positif dalam hidupnya.

Berdasarkan fenomena yang ada, maka rumusan masalah dalam penelitian ini adalah "apakah terdapat hubungan penerimaan diri dengan kebersyukuran pada siswa?"

\section{Metode Penelitian}

Penelitian ini adalah penelitian korelasi yang bertujuan mengungkap hubungan antar variabel. Variabel terikat dalam penelitian ini adalah kebersyukuran yang diukur dengan skala kebersyukuran 
yang diadaptasi dari Listiyandini (2015) yang meliputi aspek memiliki rasa apresiasi, perasaan positif terhadap kehidupan yang dimiliki, dan kecenderungan untuk bertindak positif.

Varibel bebas dalam penelitian ini yaitu penerimaan diri yang diukur dengan skala penerimaan diri yang diadaptasi dari Allport yang meliputi aspek memiliki gambaran yang positif tentang dirinya, dapat mengatur dan dapat bertoleransi dengan rasa frustasi dan kemarahannya, dapat berinteraksi dengan orang lain tanpa memusuhi mereka apabila orang lain beri kritik, dan dapat mengatur keadaan emosi mereka.

Penelitian ini dilakukan di Madarasah Aliyah Bilingual yang terletak di Krian, Sidoarjo. Dilakukan pada 96 siswa Bilingual kelas XI dan XII MA. Sebanyak 42\% subjek berjenis laki-laki dan $58 \%$ berjenis kelamin perempuan. Dalam hal ini subjek perempuan lebih banyak daripada subjek lakilaki. Dari 96 subjek yang menjadi sampel dalam penelitian, dengan rentang usia 16 tahun sebanyak $3 \%$, usia 17 tahun sebanyak 45\%, usia 18 tahun sebanyak 50\%, dan usia 19 tahun sebanyak 2\%. Dalam hal ini subjek dengan usia 18 tahun adalah yang paling banyak daripada subjek dengan usia lain.

Skala kebersyukuran dan skala penerimaan diri dalam penelitian ini disajikan dalam bentuk skala likert yang terdiri dari lima alternatif jawaban dari masing-masing aitem, yaitu Sangat Sesuai (SS), Sesuai (S), Ragu-Ragu (R), Tidak Sesuai (TS), Sangat Tidak Sesuai (STS). Skala ini terdiri dari kategori aitem pernyataan, yaitu favorable dan unfavorable serta menentukan bobot nilai.Untuk aitem favorable, skor dimulai dari 5, 4, 3, 2, 1.Sementara untuk aitem unfavorable, skor dimulai dari 1, 2, 3, 4, 5 .

Dalam kegiatan tryout untuk menguji validitas dan reliabilitas alat ukur, peneliti melakukan uji coba pada 50 siswa. Yang menghasilkan 17 aitem skala kebersyukran dan 34 aitem skala penerimaan diri yang valid. Hasil uji reliabilitas dari skala kebersyukran yaitu 0.905 dan skala penerimaan diri yaitu sebesar 0.867. Kedua variabel memiliki reliabilitas yang sangat baik, artinya aitem-aitemnya reliable sebagai alat pengumpul data dalam penelitian ini. Dikatakan reliable karena nilai koefisien reliabilitas lebih dari 0.700 (Azwar, 2013). Teknik pengumpulan data dalam penelitian ini yaitu dengan quota sampling dan dianalisis menggunakan product moment.

Dari hasil uji normalitas sebaran menggunakan One Sample Kolmogorov-Smirnov Test diperoleh nilai signifikansi sebesar $0.196>0.05$, artinya data berdistribusi normal dan memenuhi asumsi uji normalitas. Hasil uji linieritas antara variabel penerimaan diri dengan kebersyukuran menunjukkan taraf signifikansi sebesar 0.749>0.05 yang artinya variabel penerimaan diri dan kebersyukuran mempunyai hubungan yang linier. Berdasarkan hasil uji prasyarat data yang dilakukan melalui uji normalitas sebaran kedua variabel baik variabel penerimaan maupun variabel kebersyukuran, keduanya dinyatakan normal.Demikian juga dengan melalui uji linieritas hubungan keduanya dinyatakan korelasinya linier. Hal ini menunjukkan bahwa kedua variabel tersebut memiliki syarat untuk dianalisis menggunakan teknik korelasi product moment.

Analisis product moment atau disebut juga korelasi pearson merupakan analisis korelasi untuk statistik parametrik, yaitu mengukur hubungan antara dua variabel. Dalam hal ini variabel yang diukur yaitu variabel penerimaan diri dengan variabel kebersyukuran. Hasil analisis variabel dapat dilihat pada tabel 1 dibawah ini:

Tabel 1 Analisis Product Moment

\begin{tabular}{|c|c|c|c|}
\hline & & Kebersyukuran & Penerimaan Diri \\
\hline \multirow{3}{*}{ Kebersyukuran } & $\begin{array}{l}\text { Pearson } \\
\text { Correlation }\end{array}$ & 1 & .178 \\
\hline & Sig. (2-tailed) & & .082 \\
\hline & $\mathrm{N}$ & 96 & 96 \\
\hline \multirow{2}{*}{ Penerimaan Diri } & $\begin{array}{l}\text { Pearson } \\
\text { Correlation }\end{array}$ & .178 & 1 \\
\hline & $\begin{array}{l}\text { Sig. (2-tailed) } \\
\mathrm{N}\end{array}$ & $\begin{array}{c}.082 \\
96\end{array}$ & 96 \\
\hline
\end{tabular}

Berdasarkan hasil uji analisis product moment pada tabel 1, didapatkan nilai signifikansi 0.082 , karena signifikansi $>0.05$, maka hipotesis nol (Ho) diterima dan hipotesis alternative (Ha) ditolak. Artinya tidak terdapat hubungan antara Penerimaan Diri dengan Kebersyukuran padasiswa MA 
Bilingual. Hal ini selaras dengan penelitian yang dilakukan oleh Praboeo (2016), yang menyatakan bahwa penerimaan diri yang merupakan salah satu aspek dari psychological well-being tidak memiliki hubungan dengan kebersyukuran.

\section{Pembahasan}

Berdasarkan hasil penelitian menunjukkan bahwa tidak terdapat hubungan antara penerimaan diri dengan kebersyukuran dengan nilai signifikansi yang diterima yaitu 0.082. Ada beberapa hal kemungkinan yang menyebabkan hipotesis ditolak. Menurut Widhiarso (2012) karena adanya aitem dalam alat ukur yang bersifat normatif atau social desirabel sehinga menjadikan jawaban sampel penelitian menyetujui pernyataan dalam aitem. Menurut Azwar (2011) isi aitem tidak boleh mengandung social desirability, yaitu aitem yang isinya sesuai dengan keinginan social umumnya, atau dianggap baik oleh norma sosial. Aitem bermuatan social desirability cenderung untuk disetujui oleh semua orang.variabel tergantung yang diangkat dalam penelitian ini adalah bersyukur, bersyukur dalam konsep islam bersifat normatif, beberapa aitem dalam skala bersyukur yang bermuatan tentang pujian kepada Allah, menginat Allah termasuk aitem yang mengandung social desirability. Sehingga menjadikan sampel penelitian menyetujui pernyataan pada aitem skala bersyukur yang bersifat normatif. Selain aitem yang bersifat normative, penyebab hasil uji hipotesis tidak signifikan dimungkinkan karena operasionalisasi konsep yang kurang tepat.Menurut Azwar (2011) kejelasan konsep menganai atribut yang hendak diukur memungkinkan perumusan indikator-indiktor perilaku yang menunjukkan adanya atribut yang saling berhubungan dan terukur.Kurang mengoperasionalkan konsep teoritik dapat melahirkan aitem yang kurang valid.

Hasil uji yang tidak signifikan bukan berarti menunjukkan bahwa terdapat kesalahan, hal ini dapat juga disebabkan berbedanya hasil penelitian dengan hasil wawancara sebelum melakukan penelitian.Berdasarkan hasil wawancara siswa menunjukkan tanda-tanda kebersyukuran, sedangkan pada hasil penelitian menunjukkan ketidakbersyukuran.Selain itu juga dapat juga dikarenakan keadaan siswa ketika dilakukan wawancara berbeda dengan keadaan ketika skala diberikan.Perbedaan kondisi itu dapat juga membuat respon jawaban yang diberikan tidak sesuai dengan kondisi yang diharapkan bukan berdasarkan pada keadaan yang sebenarnya.Dalam hal ini sesuai dengan pendapat Azwar (2011) yang menyatakan bahwa responden memberikan respon yang sesungguhnya dan sesuai dengan kedaan dirinya sendiri sehingga data informasi psikologis yang diperoleh merupakan data yang reliabel.

Tidak signifikansinya hasil uji hipotesis dapat juga disebabkan pengaruh faktor-faktor dari bersyukur yaitu positive affect, perasaan positif yang dirasakan remaja menjadikan remaja merasakan nilai-nilai positif disekitarnya, seperti perasaan gembira, senang, dan rasa bersyukur. Menurut Seligman (2005) orang-orang dengan afek positif tinggi lebih merasa nyaman menikmati waktunya. Hal-hal baik memberikan kegembiraan dan keceriaan.Seseorang yang memiliki afek positif tinggi menurut Tellegen (Diponegoro, 2010) ditandai dengan energy yang tinggi, rasa kenyamanan dan penuh konsentrasi.Sedangkan seseorang dengan afek positif yang rendah ditandai dengan kesedihan, tidak bersemangat.

Menurut Mc.Cullough, dkk (2002) salah satu faktor yang mempengaruhi bersyukur adalah religiousness. Religiusitas remaja berkaitan pemahaman remaja dengan niali-nilai keagamaan yang diyakininya.Pemahaman remaja terhadap nilai-nilai agama mempengaruhi remaja dalam bersyukur.Semakin remaja memahami niali-nilai yang terkandung dalam bersyukur, maka semakin bersyukur.Menurut Rahmat (Puspitasari, dkk, 2005) sebagian remaja memperoleh ketenangan dalam menjalani agamanya.Selain itu, agama memberikan kerangka moral sehingga remaja dapat membendingkan tingkah lakunya.

Hal ini didukung oleh penelitian-penelitian sebelumnya. Penelitian yang dilakukan oleh Prabowo (2016) yang menunjukkan bahwa tidak ada hubungan antara penerimaan diri dengan kebersyukuran. Meskipun dalam penelitian tersebut penerimaan diri siswa diuji dengan menggunakan skala psychological well-being, menunjukkan nilai yang tidak signifikan terhadap kebersyukuran.

Menurut penelitian puspitasari (2005) yang berjudul hubungan komitmen beragama dengan subjective well-being menunjukkan bahwa semakin tinggi intensitas remaja bertingkah laku sesuai dengan ajaran agamanya maka semakin baik pula evaluasi remaja terhadap hidupnya.Dalam hal ini menunjukkan bahwa pemahaman serta melakukan nilai-nilai agama lebih memberi pengaruh terhadap 
penerimaan diri, dimana penerimaan diri merupakan aspek dari subjectif well-being.Menurut Braden (2004) menyebutkan bahwa agama memberikan makna pada kehidupan.

Bersyukur menjadikan sesorang merasa bahagia, optimis, dan merasakan kenikmatan dan merima dirinya apa adanya (Froh, dkk 2008), berdasarkan penjelasan tersebut menunjukkan bahwa penerimaan diri muncul karena bersyukur, bukan sebaliknya bahwa penerimaan diri mempengaruhi bersyukur. Hal ini sejalan dengan penelitian Emmons \& McCollough (2003) yang berjudul Counting Blessing Versus Burdens: An Experimental Investigation of Gratitude and Subjective Well Bieng in Daily Life yang hasilnya adalah bahwa siswa yang bersyukur dengan mencatat kebaikan yang diterimanya menunjukkan peningkatan hubungan social, kesahatan yang meningkat, merasakan kepuasan hidup serta merasa bahagia.

\section{Kesimpulan}

Berdasarkan hasil penelitian ini maka dapat disimpulkan bahwa tidak ada hubungan antara penerimaan diri (self-acceptance) dengan kebersyukuran (gratitude) pada siswa MA Bilingual. Hal ini didukung oleh penelitian-penelitian sebelumnya bahwa penerimaan diri tidak menjadi satu-satunya faktor yang mempengaruhi kebersyukuran siswa. Banyak faktor yang mempengaruhinya seperti positive affect dan religiusitas.

\section{Daftar Pustaka}

Ali, M. \& Asrori, M. (2012). Psikologi Remaja Perkembangan Peserta Didik. Jakarta: Bumi Aksara.

American Heritage Dictionary of the English Language. (2009). Hoghton Mifflin Company: USA.

Amin, M. (2009). Syukur (Pujian, Terima Kasih) Pusat Studi AlQur'an.www.psq.or.id/ensiklopedia_detail.asp?mnid=34\&id=119. (diakses tanggal 2 Maret 2018).

Ananwong, D., Tuicomepee, A., \& Kotrajaras, S. (2013). Self-Acceptance of Sexual Orientation in Gay Men: A Consensual Qualitative, Thailand: Chularlongkorn University.

Aricioglu, A. (2016). Mediating the Effect of Gratitude in the Relationship between Forgiveness and Life Satisfaction among University Students. International Journal of Higher Education. Vol 5, No. 2

Azwar, S. (2011). Validitas dan Reliabilitas. Yogyakarta : Pustaka Pelajar

Azwar, S. (2011). Metode Penelitian. Yogyakarta : Pustaka Pelajar

Bernand, M. E. (2013). The Strength of Self-Acceptance (Theory, Practice, and Research). Melbourne, Australia: Springer New York Heidelberg Dordrecht London.

Diponegoro, A.M. (2010). Psikologi Konseling Islami dan Psikologi Positif. Yogyakarta : UAD Press

Emmons, R. A., \& McCullough, M.E. (2003). Counting blessing versus burdens: An experimental investigation of gratitude and subjective well-being in daily life. Journal of Personality and Social Psychology. Vol. 84, No. 2, $377-389$

Fiest, J., \& Fiest, G. J. (2009). Theories of Personality (7th ed.) Singapore: McGraw-Hill.

Fitzgerald, P. (1998). Gratitude and Justice. Ethics, 109, 119-153

Froh, J. J., Kashdan, T. B., Ozimkowski, K. M, and Miller, N. (2009). Who Benefits The Most frim A Gratitude Intervention in Children and Adolescents? Examining Positive Affect as A Moderator. Journal of Positive Psychology. 4 (5): 408-422.

Froh, J.J., Bono, G., \& Emmons, R.A. (2010). Being Grateful id Beyond Good Manners: Gratitude and Motivation to Contribute to Society among Early Adolescents. Motivation Emotion, 34, 144-157. doi: 10.1007/s1031-010-9163-z

Froh, J.J., Yurkewicz, C., \& Kashdan, T.B. (2009). Gratitude and Subjective Well-Being in Early Adolesence: Examining Gender Differences. Journal of Adolesence. doi: 10.1016/j.adolesence.2008.06.006.

Hambali, A., Meiza, A., \& Fahmi, I. (2015). Faktor-Faktor yang Berperan dalam Kebersyukuran (Gratitude) pada Orangtua Anak Berkebutuhan Khusus Perspektif Psikologi Islam. Psympathic, Jurnal Ilmiah Psikologi, 2 (1), 94101.

Hurlock, E. B. (2009). Psikologis Perkembangan : Suatu Pendekatan Sepanjang RentangKehidupan. Jakarta : Erlangga

Kristanto, E. (2016). Perbedaan Tingkat Kebersyukuran pada Laki-Laki dan Perempuan. Dipresentasikan pada Seminar ASEAN 2 ${ }^{\text {nd }}$ Psychology and Humanity, Malang. 
Lambert, N. M., Graham, S. M., \& Finchan, F. D. (2009). A Prototype Analysis of Gratitude: Varieties of Gratitude Experiences. Personality Social Psychology Bulletin, 35, 1193-1207.

Listiyandini, R.A. (2015). Mengukur Rasa Syukur: Pengembangan Model Awal Skala Bersyukur Versi Indonesia. Jurnal Psikologi Ulayat. Vol.2. No.2, 473-496.

Murniasih, F. (2013). Pengaruh Kecerdasan Emosi dan rasa Syukur terhadap Psychological Well-Being pada remaja. Skripsi (tidak diterbitkan). Program Studi Psikologi Universitas Udayana Bali.

Papilia, D. E., Olds, S. W., Feldman, R.D. (2009). Human Development. Jakarta: Salemba.

Peterson, C., \& Seligman, M. E. P. (2004). Character Strength and Virtues: A Handbook \& Classification. New York: Oxford University Press.

Prabowo, A. (2017). Gratitude dan Psychological Well-Being pada Remaja. Jurnal Psikologi JIPT. Vol 05. No 02.

Putri, G.G., Agusta, P., Najahi, S. (2013). Perbedaan Self-Acceptance (Penerimaan Diri) pada Anak Panti Asuhan Ditinjau dari Segi Usia. Jurnal Proceeding PESAT. Vol 5.

Putri, O. F. (2012). Hubungan Antara Gratitude dan Psychological Well-Being pada Mahasiswa. Skripsi (tidak diterbitkan). Fakultas Psikologi Universitas Indonesia, Jakarta.

Robustelli, B.L., \& Whisman, M.A. (2016). Gratitude and Life Satisfaction in the united States and Japan. Journal Happiness Study.

Rotkirch, A. (2014). Gratitude For Help Among Adult Friends and Diblings. The Journal of Evolutionary Psychology, 12, (4): 673-686.

Said, A. M., (2015). Mendidik Remaja Nakal. Jakarta: Semesta Hikmah.

Salim, P. Sagita. (2015). Hubungan antara Rasa Syukur dengan Optimisme pada Santri Pondok Pesantren Modern Islam Assalaam. Naskah publikasi. Universitas Muhamadiyah Surakarta.

Salvador, C., \& Ferrer. (2017). The Relationship between Gratitude and Life Satisfaction in a Sample of Spanish University Student: The Moderation Role of Gender. Psychology Journal. Vol 33. No 1, 114-119

Sarwono, W. S. (2012). Psikologi Remaja. Jakarta: Rajawali Pers.

Syarbini, A. (2011). Dahsyatntya Sabar, Syukur, dan Ikhlas Muhammad SAW. Jakarta: Ruang Kata.

Van Cappellen, P., \& Rime', B. (2014). Positive emotions and self-transcendence. In V. Saroglou (Ed.), Religion, personality, and social behavior. New York, NY: Psychology Press.

Wicaksono, M.L.H., \& Susilawati, L.K.P.A. (2016). Hubungan Rasa Syukur dan Perilaku Prososial terhadap Psychological Well-Being pada Remaja Akhir Anggota Islamic Medical Activity Fakultas Kedokteran Universitas Udayana. Jurnal Psikologi Udayana. Vol 3. No 2.

Wood, A. M., Joseph, S., \& Linley, P. A. (2009). Gratitude: The Parent of All Virtues. The Psychologist, $20,18-21$.

Wood, A. M., Joseph, S., \& Maltby, J. (2009). Gratitude Predicts Psychological Well-Being Above The Big Five Facets. Journal of Personality and Individual Different. Vol. 46, No. 10, $443-447$. 